\title{
Berat bayi lahir dan kejadian stunting pada anak usia 6-59 bulan di Kecamatan Seberang Ulu I Palembang
}

\author{
Indah Purnama Sari $^{1 *}$, Yustini Ardillah ${ }^{2}$, Anita Rahmiwati ${ }^{1}$
}

\begin{abstract}
Background: Stunting is an indicator of chronic nutritional problem among children under five years old that influenced by nutrition and health status of mothers not only before and during prenancy but also after delivery. One of the long-term effects of stunting is increasing the risk of obesity and other non-communicable diseases. Low birth weight is one of the causes of stunting which also indicates that the fetus has been malnourished during the womb and stunting is a manifestation of malnutrition for a long time.

Objectives: This study aimed to determine of the association between low birth weight and stunting, as well as other variables among children between the ages of 6 to 59 months.

Methods: This study used cross sectional design. Samples consisted of about 188 eligible children between the ages of 6 to 59 months which selected using simple random sampling technique. Data of the mother's, infants and environmental characteristics were obtained through face-to-face interviews using a structured questionnaire. Data on birth weight and length were obtained from interviews and crosscheck from the Maternal and Child Health book or child birth records and data on stunting obtained from height Z-score based on age. Data was analyzed using chi-square and logistic regression test.

Results: The prevalence of stunting and low birth weight among children between the ages of 6 to 59 months in Seberang Ulu I subdistrict of Palembang was $39.4 \%$ and $8.5 \%$, respectively. Birth weight was related to stunting (95\% CI=1.28-2.76; $p=0.012)$ and other variables like infectious diseases in the last 1 month $(95 \% \mathrm{CI}=1.13-2.26 ; p=0.009)$, maternal height $(95 \%$ $\mathrm{CI}=1.10-2.19 ; p=0.016)$ and household monthly income (95\% $\mathrm{CI}=1.04-2.28 ; p=0.024)$.

Conclusion: Children with low birth weight had risk of stunting 2.29 higher than children with normal weight after controlling for other factors such as child's age, mother's age during delivery, availability of latrine and household monthly income.
\end{abstract}

Keywords : stunting; low birth weight; children under five

\section{ABSTRAK}

Latar Belakang : Stunting merupakan indikator permasalahan gizi kronis pada balita yang dipengaruhi oleh kondisi kesehatan dan gizi ibu sebelum, saat kehamilan dan setelah persalinan. Adapun salah satu dampak jangka panjang balita yang mengalami stunting adalah meningkatkan risiko obesitas dan penyakit tidak menular lainnya. Berat bayi lahir rendah merupakan salah satu penyebab stunting pada balita yang menandakan pula janin telah mengalami malnutrisi selama didalam kandungan dan stunting merupakan manifes kondisi malnutrisi dalam jangka waktu lama.

Tujuan : Penelitian ini bertujuan mengetahui hubungan BBLR dengan kejadian stunting pada anak usia 6-59 bulan beserta variabel lainnya.

Metode : Penelitian ini menggunakan desain potong lintang. Sampel sebanyak 188 balita yang berusia 6-59 bulan yang dipilih dengan menggunakan teknik acak sederhana. Data karakteristik ibu, balita dan lingkungan diperoleh melalui wawancara tatap muka dengan menggunakan kuesioner terstruktur. Data berat bayi lahir dan panjang badan lahir didapatkan dari wawancara dan crosscheck dari buku Kesehatan Ibu dan Anak (KIA) atau catatan kelahiran anak dan data balita stunting diperoleh dari hasil Z-score TB atau PB berdasarkan usia. Analisis data menggunakan uji Chi-Square dan uji regresi logistik ganda.

Hasil : Prevalensi stunting pada anak usia 6-59 bulan di Kecamatan Seberang Ulu I sebesar 39,4\% dan proporsi BBLR sebesar 8,5\%. Berat bayi lahir berhubungan dengan kejadian stunting (95\% CI=1,28-2,76; $p=0,012)$ dan variabel lain yang berhubungan dengan kejadian stunting adalah penyakit infeksi dalam 1 bulan terakhir $(95 \% \mathrm{CI}=1,13-2,26 ; p=0,009)$, tinggi badan ibu (95\% CI=1,10-2,19; $p=0,016)$ dan pendapatan keluarga per bulan $(95 \% \mathrm{CI}=1,04-2,28 ; p=0,024)$.

Simpulan : Anak dengan BBLR memiliki risiko stunting 2,29 kali lebih tinggi dibandingkan anak dengan berat lahir normal setelah dikontrol oleh variabel usia anak, usia ibu saat melahirkan, kepemilikan jamban dan pendapatan keluarga per bulan.

Kata Kunci : stunting; berat badan lahir rendah; bawah lima tahun

\section{PENDAHULUAN}

Stunting (kerdil) adalah suatu kondisi yang dialami bayi bawah lima tahun (balita) yang memiliki panjang atau tinggi badan yang jika dibandingkan dengan usia lebih dari minus dua standar deviasi median standar pertumbuhan anak dari World Health Organization (WHO). Balita pendek (severe stunting

\footnotetext{
${ }^{1}$ Program Studi Gizi, Fakultas Kesehatan Masyarakat, Universitas Sriwijaya. Gedung Fakultas Kesehatan Masyarakat, Kampus Unsri Indralaya, Ogan Ilir 30662, Indonesia.

${ }^{2}$ Program Studi Kesehatan Lingkungan, Fakultas Kesehatan Masyarakat, Universitas Sriwijaya. Gedung Fakultas Kesehatan Masyarakat, Kampus Unsri Indralaya, Ogan Ilir 30662, Indonesia.

*Korespondensi : E-mail: indah_purnamasari@fkm.unsri.ac.id
} 
dan stunting) merupakan salah satu permasalahan gizi yang dialami oleh balita tidak hanya di Indonesia namun juga di dunia. Sebanyak 150,8 juta $(22,2 \%)$ balita mengalami stunting pada tahun 2017 dengan penyumbang terbesar yaitu Asia (55\%) dan Afrika (39\%). Kawasan Asia Selatan $(58,7 \%)$ merupakan negara penyumbang proporsi terbanyak balita stunting. Sementara itu, Indonesia yang berada di kawasan Asia Tenggara, menempati posisi kedua prevalensi tertinggi dengan rata-rata prevalensi balita stunting sebesar $36,4 \%$ setelah negara Timor Leste $(50,2 \%) .{ }^{1}$ Berdasarkan hasil Riset Kesehatan Dasar (Riskesdas), prevalensi pendek (stunting) pada balita mengalami penurunan dalam jangka waktu lima tahun yaitu sebanyak 37,2\% (2013) menjadi 30,8\% (2018). Sementara itu, prevalensi stunting pada anak usia 0-23 bulan (baduta) yaitu sebesar 29,9\%. Namun, permasalahan stunting di Indonesia masih merupakan masalah kesehatan masyarakat yang dianggap berat yaitu 30-39\% berdasarkan ketetapan WHO. ${ }^{2}$

Stunting juga merupakan salah satu target tujuan pembangunan berkelanjutan atau yang lebih dikenal dengan Sustainable Development Goals (SDGs) poin 2 yaitu menghilangkan kelaparan dan segala bentuk malnutrisi pada tahun 2030 dengan target menurunkan angka stunting hingga $40 \%$ pada tahun 2025. Perhatian besar WHO pada stunting disebabkan oleh karena dampak yang ditimbulkan stunting baik dalam waktu jangka pendek maupun jangka panjang. Adapun dampak jangka pendek yang akan dialami oleh balita yang mengalami stunting adalah peningkatan kejadian kesakitan dan kematian, perkembangan kognitif, motorik dan verbal pada anak menjadi tidak optimal, dan adanya peningkatan biaya kesehatan. Selain itu, balita stunting juga akan mengalami dampak pada jangka panjang antara lain postur tubuh yang tidak optimal saat dewasa (lebih pendek dibandingkan pada umumnya), meningkatkan risiko obesitas dan penyakit tidak menular lainnya, menurunnya kesehatan reproduksi, kapasitas belajar dan performa yang kurang optimal pada saat masa sekolah serta produktivitas dan kapasitas kerja yang tidak optimal. ${ }^{1}$

Salah satu penyebab kejadian stunting pada balita adalah riwayat berat bayi lahir rendah (BBLR). BBLR merupakan suatu keadaan bayi yang lahir dengan berat badan kurang dari 2500 gram tanpa melihat masa kehamilan. Bayi BBLR dalam kondisi dismature telah mengalami retardasi pertumbuhan interauterin (sejak dalam kandungan) dan akan berlanjut sampai setelah dilahirkan yaitu mengalami hambatan pertumbuhan yang berkaitan dengan maturitas otak, perkembangan kognitif, motorik dan verbal yang lebih lambat dari bayi dengan berat lahir normal, kegagalan dalam menyusul tingkat pertumbuhan yang seharusnya dicapai pada usia setelah lahir, dan mengalami gangguan pada saluran pencernaan yang dapat menghambat penyerapan dan pencernaan berbagai zat gizi sehingga mengakibatkan kurangnya cadangan zat gizi dalam tubuh. ${ }^{3}$

Beberapa hasil penelitian sebelumnya di Indonesia mengemukakan bahwa berat bayi lahir rendah berpengaruh terhadap kejadian stunting pada balita antara lain penelitian Nasution et al. (2014) yang menunjukkan bahwa bayi dengan riwayat BBLR berisiko 5,7 kali lebih tinggi mengalami stunting (95\% CI: 2,4-13,6), Lestari et al. (2014) yang mengemukakan bahwa bayi dengan riwayat BBLR berisiko 3,3 kali lebih tinggi mengalami stunting (95\% CI: 1,5-7,3), Mustikaningrum et al. (2016) menemukan bahwa bayi dengan riwayat BBLR berisiko 4,1 kali lebih tinggi mengalami stunting (95\% CI: 1,6-10,0), Wellina et al. (2016) menemukan bahwa bayi dengan riwayat BBLR berisiko 3,6 kali lebih tinggi mengalami stunting (95\% CI: 1,6-17,9), Supriyanto et al. (2017) yang menyatakan bahwa bayi dengan riwayat BBLR berisiko 6,2 kali lebih tinggi mengalami stunting (95\% CI: 3,0-12,6) dan Sajalia et al. (2016) menemukan bahwa bayi dengan riwayat BBLR berisiko 15,4 kali lebih tinggi mengalami stunting (95\% CI: 4,9-47,4) dibandingkan bayi dengan berat lahir normal. ${ }^{3-7}$ Selain BBLR, berbagai faktor lain juga mempengaruhi kejadian stunting pada balita yaitu antara lain panjang badan lahir $^{7-9}$, jenis kelamin $^{10-12}$, usia anak ${ }^{11-13}$, pernah mengalami penyakit infeksi dalam minimal 2 minggu terakhir ${ }^{7,11,14}$, tinggi badan $\mathrm{ibu}^{12}$, usia ibu saat melahirkan ${ }^{7}$, praktik cuci tangan ibu $^{15,16}$, ketersediaan jamban ${ }^{10}$, sumber air minum ${ }^{12,17}$ dan pendapatan keluarga per bulan. ${ }^{5-7,12,18,19}$

Penelitian ini dilaksanakan di Provinsi Sumatera Selatan yang memiliki proporsi BBLR pada balita $(6,8 \%)$ lebih tinggi dibandingkan proporsi Nasional $(6,2 \%)$ dan prevalensi stunting pada balita juga lebih tinggi dibandingkan Nasional $(31,6 \%$ dan $30,8 \%){ }^{2}$ Berdasarkan hasil Pemantauan Status Gizi (PSG) di Kota Palembang prevalensi pendek (stunting) mengalami peningkatan dari $9,0 \%$ pada tahun 2016 menjadi $14,5 \%$ pada tahun 2017. Kecamatan Seberang Ulu I merupakan salah satu kecamatan yang berada di pinggiran Sungai Musi di Kota Palembang yang mengalami permasalahan gizi antara lain proporsi BBLR $(2,06 \%$ dan $1,13 \%)$ dan prevalensi Bawah Garis Merah pada balita $(0,66 \%$ dan $0,56 \%)$ yang masih lebih tinggi dibandingkan proporsi Kota Palembang. Sementara itu, proporsi pemberian ASI eksklusif $(66,15 \%$ dan $72,76 \%)$ dan proporsi pemberian imunisasi dasar lengkap $(95,28 \%$ dan 95,53\%) masih lebih rendah dibandingkan Kota Palembang. Selain permasalahan gizi, Kecamatan Seberang Ulu I juga mengalami permasalahan perilaku dan lingkungan yaitu sebesar 58,08\% rumah tangga berperilaku hidup bersih dan sehat (Kota Palembang sebesar 65,79\%), 76,11\% rumah yang memenuhi syarat sebagai rumah sehat (Kota Palembang sebesar 79,29\%) dan 66,07\% 
penduduk dengan akses sanitasi layak (jamban sehat) (Kota Palembang sebesar 75\%). ${ }^{20}$ Berbagai kondisi ini dapat mempengaruhi status gizi balita terutama stunting yang berdampak baik jangka pendek dan jangka panjang. Oleh karena itu, penelitian ini bertujuan mengetahui prevalensi stunting, hubungan BBLR dengan kejadian stunting dan keterkaitan faktor confounding yang mempengaruhi hubungan BBLR dengan kejadian stunting pada anak usia 6-59 bulan di Kecamatan Seberang Ulu I, Palembang.

\section{BAHAN DAN METODE}

Penelitian ini merupakan penelitian analitik kuantitatif dengan desain potong lintang. Penelitian ini berlokasi di Kecamatan Seberang Ulu I Kota Palembang. Sampel dalam penelitian ini adalah ibu yang memiliki anak yang berusia 6-59 bulan yang memenuhi kriteria inklusi (kelahiran tunggal dan anak terakhir) dan kriteria eksklusi (ibu yang pindah domilisi dan tidak bersedia menjadi responden). Perhitungan besar sampel menggunakan rumus uji hipotesis beda dua proporsi. Teknik pengambilan sampel menggunakan teknik acak sederhana (simple random sampling) dengan menggunakan kerangka sampling (sampling frame) berupa daftar pencatatan ePPGBM dan pencatatan balita di posyandu yang diperoleh dari kader, bidan posyandu dan bidan puskesmas dari tiga puskesmas (Puskesmas 1 Ulu, 4 Ulu dan 7 Ulu) yang berada di wilayah kerja Kecamatan Seberang Ulu I.

Data dikumpulkan melalui wawancara tatap muka dengan menggunakan kuesioner terstruktur meliputi karakteristik sosial demografi ibu, karakteristik balita, dan karakteristik lingkungan. Karakteristik sosial demografi ibu seperti usia ibu saat melahirkan, tinggi badan ibu dan pendapatan keluarga per bulan. Tinggi badan ibu akan dibedakan menjadi $<150 \mathrm{~cm}$ dan $\geq 150$ $\mathrm{cm}$ serta usia ibu saat melahirkan akan dibedakan menjadi $<20$ atau $>35$ tahun dan 20-35 tahun. Pendapatan keluarga per bulan dikelompokkan berdasarkan Upah Minimum Kota (UMK) yaitu dibawah Rp. 2.917.290,- dan Rp. 2.917.290,- atau lebih. Karakteristik balita seperti usia balita, jenis kelamin, berat lahir, panjang badan lahir, dan penyakit infeksi (diare dan atau ISPA) yang pernah diderita balita dalam 1 bulan terakhir. Data karakteristik lingkungan seperti ketersediaan jamban sehat, sumber air minum dan perilaku cuci tangan ibu. Praktik cuci tangan ibu terdiri dari beberapa pertanyaan antara lain selalu mencuci tangan dengan menggunakan sabun, menggunakan air mengalir, mencuci tangan sebelum mempersiapkan makanan, mencuci tangan setelah memegang uang, binatang atau berkebun, setelah menceboki balita, setelah menggunakan insektisida. Ibu yang melakukan keseluruhan perilaku ini akan terkelompokkan menjadi "baik" dan "kurang baik" jika ibu tidak melakukan keseluruhan perilaku cuci tangan ini. Ketersediaan jamban dibedakan menjadi "ya" jika memiliki jamban sehat yang memiliki septictank dan "tidak" jika tidak memiliki jamban sehat. Sumber air minum akan dibedakan menjadi PDAM dan bukan PDAM. Pengukuran tinggi badan menggunakan stadiometer sedangkan panjang badan menggunakan infantometer.

Tabel 1. Karakteristik Balita di Kecamatan Seberang Ulu I Palembang

\begin{tabular}{|c|c|c|}
\hline Variabel & $\mathbf{n}$ & $\%$ \\
\hline \multicolumn{3}{|l|}{ Stunting } \\
\hline Tidak & 114 & 60,6 \\
\hline $\mathrm{Ya}$ & 74 & 39,4 \\
\hline \multicolumn{3}{|l|}{ Berat badan lahir } \\
\hline Tidak BBLR & 172 & 91,5 \\
\hline BBLR & 16 & 8.5 \\
\hline \multicolumn{3}{|l|}{ Panjang badan lahir } \\
\hline$\geq 48 \mathrm{~cm}$ & 120 & 63,8 \\
\hline$<48 \mathrm{~cm}$ & 68 & 36,2 \\
\hline \multicolumn{3}{|l|}{ Jenis kelamin } \\
\hline Laki-laki & 98 & 52,1 \\
\hline Perempuan & 90 & 47,9 \\
\hline \multicolumn{3}{|l|}{ Usia anak } \\
\hline 24-59 bulan & 130 & 69,1 \\
\hline $6-23$ bulan & 58 & 30,9 \\
\hline \multicolumn{3}{|c|}{$\begin{array}{l}\text { Penyakit infeksi dalam } 1 \text { bulan } \\
\text { terakhir }\end{array}$} \\
\hline Tidak & 118 & 62,8 \\
\hline $\mathrm{Ya}$ & 70 & 37,2 \\
\hline \multicolumn{3}{|l|}{ Tinggi badan ibu } \\
\hline$\geq 150 \mathrm{~cm}$ & 126 & 67,0 \\
\hline$<150 \mathrm{~cm}$ & 62 & 33,0 \\
\hline \multicolumn{3}{|c|}{ Usia ibu saat melahirkan } \\
\hline 20-35 tahun & 144 & 76,6 \\
\hline$<20$ atau $>35$ tahun & 44 & 23,4 \\
\hline \multicolumn{3}{|c|}{ Praktik cuci tangan ibu } \\
\hline Higienis & 54 & 28,7 \\
\hline Kurang higienis & 134 & 71,3 \\
\hline \multicolumn{3}{|c|}{ Kepemilikan jamban sehat } \\
\hline $\mathrm{Ya}$ & 168 & 89,4 \\
\hline Tidak & 20 & 10,6 \\
\hline \multicolumn{3}{|l|}{ Sumber air minum } \\
\hline Bukan PDAM & 67 & 35,6 \\
\hline PDAM & 121 & 64,4 \\
\hline \multicolumn{3}{|c|}{ Pendapatan keluarga/bulan } \\
\hline$\geq \mathrm{UMK}$ & 80 & 42,6 \\
\hline$<\mathrm{UMK}$ & 108 & 57,4 \\
\hline
\end{tabular}

Sumber: Data Primer (2019)

Berat bayi lahir sebagai variabel independen utama dan panjang badan lahir didapatkan dari wawancara dan crosscheck dari buku Kesehatan Ibu dan Anak (KIA) atau catatan kelahiran anak. Berat badan lahir dikategorikan menjadi 2 yaitu berat bayi lahir rendah (BBLR) jika berat bayi lahir <2500 gram dan tidak BBLR apabila minimal 2500 gram. Panjang badan lahir juga dikategorikan menjadi 2 yaitu panjang badan lahir $<48 \mathrm{~cm}$ dan minimal $48 \mathrm{~cm}$. Variabel terikat 
adalah kejadian stunting. Kejadian stunting dikategorikan menjadi 2 yaitu stunting (pendek) jika indeks TB/U atau PB/U dengan nilai z-score <-2SD dan tidak stunting jika nilai $z$-score $\geq-2 \mathrm{SD}$. Analisis data menggunakan uji Chi-Square menampilkan nilai Prevalensi Rasio (PR) secara kasar (unadjusted) dan uji regresi logistik ganda dengan pemodelan faktor risiko sehingga menghasilkan nilai ukuran asosiasi yang telah terkontrol (adjusted).

\section{HASIL}

\section{Karakteristik Balita}

Jumlah anak yang berusia 6-59 bulan dalam penelitian ini yakni 188 orang. Hasil penelitian (Tabel 1) menunjukkan prevalensi stunting pada anak usia 659 bulan di Kecamatan Seberang Ulu I sebesar 39,4\%. Hal ini menunjukkan bahwa sebanyak 3 sampai 4 anak dari 10 anak balita mengalami stunting. Sementara itu, sebanyak 8,5\% anak lahir dengan berat badan lahir kurang dari 2500 gram dan sebanyak 36,2\% memiliki panjang badan lahir kurang dari $48 \mathrm{~cm}$. Proporsi anak laki-laki lebih banyak 4,2\% dibandingkan anak perempuan dengan usia 24-59 bulan lebih banyak $39,8 \%$ dibandingkan usia 6-23 bulan. Selain itu, sebanyak 3 sampai 4 anak dari 10 anak mengalami penyakit infeksi (diare dan atau ISPA) dalam 1 bulan terakhir $(37,2 \%)$. Anak yang memiliki ibu dengan tinggi badan kurang dari $150 \mathrm{~cm}$ lebih sedikit $34 \%$ dibandingkan ibu dengan tinggi badan minimal $150 \mathrm{~cm}$ dan usia ibu saat melahirkan kurang dari 20 tahun dan atau lebih 35 tahun sebesar 23,4\%. Sebanyak 7 dari 10 ibu dengan praktik cuci tangan yang kurang higienis $(71,3 \%)$ dan sebanyak 11 dari 100 rumah tangga yang belum memiliki jamban sehat (yang memiliki septictank) (10,6\%). Masih terdapat rumah tangga yang menggunakan sumber air minum yang bukan berasal dari PDAM sebanyak 35,6\% dan terdapat 5 sampai 6 dari 10 rumah tangga dengan pendapat keluarga per bulan di bawah UMK $(57,4 \%)$.

Tabel 2. Hubungan Berat Badan Lahir dan Faktor Lainnya dengan Kejadian Stunting

\begin{tabular}{|c|c|c|c|c|c|c|}
\hline \multirow{3}{*}{ Variabel } & \multicolumn{4}{|c|}{ Kejadian Stunting } & \multirow{3}{*}{ PR $(95 \% \text { CI })^{*}$} & \multirow{3}{*}{$p^{\#}$} \\
\hline & \multicolumn{2}{|c|}{ Stunting } & \multicolumn{2}{|c|}{ Tidak Stunting } & & \\
\hline & $\mathbf{n}$ & $\%$ & $\mathbf{n}$ & $\%$ & & \\
\hline \multicolumn{7}{|l|}{ Berat badan lahir } \\
\hline Tidak BBLR & 63 & 36,6 & 109 & 63,4 & Ref & \multirow{2}{*}{0,025} \\
\hline BBLR & 11 & 68,8 & 5 & 31,2 & $1,88(1,28-2,76)$ & \\
\hline \multicolumn{7}{|l|}{ Panjang badan lahir } \\
\hline$\geq 48 \mathrm{~cm}$ & 45 & 37,5 & 75 & 62,5 & Ref & \multirow{2}{*}{0,590} \\
\hline$<48 \mathrm{~cm}$ & 29 & 42,6 & 39 & 57,4 & $1,14(0,79-1,63)$ & \\
\hline \multicolumn{7}{|l|}{ Jenis kelamin } \\
\hline Laki-laki & 37 & 37,8 & 61 & 62,2 & Ref & \multirow{2}{*}{0,748} \\
\hline Perempuan & 37 & 41,1 & 53 & 58,9 & $0,92(0,64-1,31)$ & \\
\hline \multicolumn{7}{|l|}{ Usia anak } \\
\hline 24-59 bulan & 55 & 42,3 & 75 & 57,7 & Ref & \multirow{2}{*}{0,282} \\
\hline $6-23$ bulan & 19 & 32,8 & 39 & 67,2 & $1,29(0,85-1,97)$ & \\
\hline \multicolumn{7}{|c|}{ Penyakit infeksi dalam 1 bulan terakhir } \\
\hline Tidak & 38 & 32,2 & 80 & 67,8 & Ref & \multirow{2}{*}{$0,014^{*}$} \\
\hline Iya & 36 & 51,4 & 34 & 48,6 & $1,59(1,13-2,26)$ & \\
\hline \multicolumn{7}{|l|}{ Tinggi badan ibu } \\
\hline$\geq 150 \mathrm{~cm}$ & 32 & 51,6 & 30 & 48,4 & Ref & \multirow[t]{2}{*}{$0,024^{\ddagger}$} \\
\hline$<150 \mathrm{~cm}$ & 42 & 33,3 & 84 & 66,7 & $1,55(1,10-2,19)$ & \\
\hline \multicolumn{7}{|l|}{ Usia ibu saat melahirkan } \\
\hline 20-35 tahun & 56 & 38,9 & 88 & 61,1 & Ref & \multirow{2}{*}{0,949} \\
\hline$<20$ atau $>35$ tahun & 18 & 40,9 & 26 & 59,1 & $1,05(0,69-1,59)$ & \\
\hline \multicolumn{7}{|l|}{ Praktik cuci tangan ibu } \\
\hline Higienis & 19 & 35,2 & 35 & 64,8 & Ref & \multirow{2}{*}{0,563} \\
\hline Kurang higienis & 55 & 41,0 & 79 & 59,0 & $1,17(0,77-1,77)$ & \\
\hline \multicolumn{7}{|l|}{ Kepemilikan jamban sehat } \\
\hline $\mathrm{Ya}$ & 63 & 37,5 & 105 & 62,5 & Ref & \multirow{2}{*}{0,203} \\
\hline Tidak & 11 & 55,0 & 9 & 45,0 & $1,47(0,94-2,28)$ & \\
\hline \multicolumn{7}{|l|}{ Sumber air minum } \\
\hline Bukan PDAM & 28 & 41,8 & 39 & 58,2 & Ref & \multirow{2}{*}{0,725} \\
\hline PDAM & 46 & 38,0 & 75 & 62,0 & $1,10(0,77-1,58)$ & \\
\hline \multicolumn{7}{|l|}{ Pendapatan keluarga/bulan } \\
\hline$\geq \mathrm{UMK}$ & 24 & 30,0 & 56 & 70,0 & Ref & \multirow{2}{*}{$0,035^{\text {f }}$} \\
\hline$<\mathrm{UMK}$ & 50 & 46,3 & 58 & 53,7 & $1,54(1,04-2,28)$ & \\
\hline
\end{tabular}




\section{Hubungan antara Berat Badan Lahir dan Faktor Lainnya dengan Kejadian Stunting}

Tabel 2 menunjukkan bahwa proporsi balita stunting yang lahir dengan BBLR $(68,8 \%)$ lebih tinggi dibandingkan balita stunting yang lahir dengan berat badan minimal 2500 gram $(36,6 \%)$. Balita yang lahir dengan BBLR memiliki peluang 1,9 kali lebih tinggi untuk mengalami stunting dibandingkan balita yang lahir dengan berat badan lahir tidak BBLR (95\% $\mathrm{CI}=1,28-2,76 ; p=0,012$ ). Proporsi balita stunting lebih tinggi pada balita dengan panjang badan lahir $<48 \mathrm{~cm}$ $(42,6 \%)$, berjenis laki-laki $(37,8 \%)$ dan berusia $24-59$ bulan $(42,3 \%)$. Selain itu, dari balita yang mengalami penyakit infeksi (diare dan atau ISPA) dalam 1 bulan terakhir sebanyak $51,4 \%$ mengalami stunting dibandingkan balita yang tidak mengalami penyakit infeksi (diare dan atau ISPA) dalam 1 bulan terakhir $(32,2 \%)$. Balita yang mengalami penyakit infeksi (diare dan atau ISPA) dalam 1 bulan terakhir memiliki peluang 1,6 kali lebih tinggi untuk mengalami stunting dibandingkan balita yang tidak mengalami penyakit infeksi (diare dan atau ISPA) dalam 1 bulan terakhir $(95 \% \mathrm{CI}=1,13-2,26 ; p=0,009)$.
Tabel 2 juga menjelaskan bahwa proporsi balita stunting dari ibu yang memiliki tinggi badan $<150 \mathrm{~cm}$ $(51,6 \%)$ lebih tinggi dibandingkan balita stunting dari ibu yang memiliki tinggi badan $\geq 150 \mathrm{~cm}(33,3 \%)$. Balita dari ibu dengan tinggi badan $<150 \mathrm{~cm}$ berpeluang 1,5 kali lebih tinggi untuk mengalami stunting dibandingkan balita dari ibu dengan tinggi badan $\geq 150 \mathrm{~cm} \quad(95 \% \quad \mathrm{CI}=1,10-2,19 ; \quad p=0,016)$. Sementara itu, proporsi balita stunting lebih banyak berasal dari ibu yang berusia $<20$ atau $>35$ tahun $(40,9 \%)$, dengan praktik cuci tangan yang kurang higienis $(41,0 \%)$, dengan keluarga yang tidak memiliki jamban sehat $(55,0 \%)$ dan sumber air minum berasal dari bukan PDAM (41,8\%). Selain itu, proporsi balita stunting dari keluarga dengan pendapatan keluarga per bulan dibawah UMK $(46,3 \%)$ lebih tinggi dibandingkan balita stunting dari keluarga dengan pendapatan keluarga per bulan minimal Rp 2.917.290,- (30,0\%). Balita dari keluarga dengan pendapatan keluarga per bulan dibawah UMK berpeluang 1,5 kali lebih tinggi untuk mengalami stunting dibandingkan balita dari keluarga dengan pendapatan keluarga per bulan minimal Rp 2.917.290,- (95\% CI=1,04-2,28; $p=0,024)$.

Tabel 3. Analisis Multivariat Hubungan antara Berat Badan Lahir dengan Kejadian Stunting

\begin{tabular}{|c|c|c|c|c|}
\hline \multirow{2}{*}{ Variabel } & \multicolumn{2}{|c|}{ Model Awal } & \multicolumn{2}{|c|}{ Model Akhir } \\
\hline & OR $(95 \%$ CI $) *$ & p-value & OR $(95 \% \text { CI })^{* *}$ & $p$-value \\
\hline \multicolumn{5}{|l|}{ Berat badan lahir } \\
\hline Tidak BBLR & Ref & \multirow{2}{*}{$0,017^{\#}$} & Ref & \multirow{2}{*}{$0,010^{\#}$} \\
\hline BBLR & $4,70(1,32-16,79)$ & & $4,67(1,44-15,14)$ & \\
\hline \multicolumn{5}{|l|}{ Usia anak } \\
\hline $24-59$ bulan & Ref & \multirow[t]{2}{*}{0,157} & Ref & \multirow[b]{2}{*}{0,225} \\
\hline $6-23$ bulan & $1,68(0,82-3,47)$ & & $1,52(0,77-3,00)$ & \\
\hline \multicolumn{5}{|l|}{ Usia ibu saat melahirkan } \\
\hline 20-35 tahun & Ref & \multirow[t]{2}{*}{0,470} & Ref & \multirow{2}{*}{0,666} \\
\hline$<20$ atau $>35$ tahun & $0,75(0,34-1,65)$ & & $0,85(0,39-1,79)$ & \\
\hline \multicolumn{5}{|l|}{ Kepemilikan jamban sehat } \\
\hline Tidak & Ref & \multirow[t]{2}{*}{0,188} & Ref & \multirow{2}{*}{0,185} \\
\hline $\mathrm{Ya}$ & $1,99(0,71-5,55)$ & & $1,92(0,73-5,04)$ & \\
\hline \multicolumn{5}{|l|}{ Pendapatan keluarga/bulan } \\
\hline$\geq \mathrm{UMK}$ & Ref & \multirow[t]{2}{*}{0,155} & Ref & \multirow{2}{*}{$0,040^{\#}$} \\
\hline$\overline{<} \mathrm{UMK}$ & $1,63(0,83-3,19)$ & & $1,94(1,03-3,65)$ & \\
\hline \multicolumn{5}{|l|}{ Panjang badan lahir } \\
\hline$\geq 48 \mathrm{~cm}$ & Ref & \multirow{2}{*}{0,549} & \multirow{2}{*}{-} & \\
\hline$<48 \mathrm{~cm}$ & $0,81(0,40-1,63)$ & & & \\
\hline \multicolumn{5}{|l|}{ Jenis kelamin } \\
\hline Laki-laki & Ref & \multirow{2}{*}{0,786} & \multirow[b]{2}{*}{-} & \\
\hline Perempuan & $0,92(0,48-1,74)$ & & & \\
\hline \multicolumn{5}{|c|}{ Penyakit infeksi dalam 1 bulan terakhir } \\
\hline Tidak & Ref & \multirow{2}{*}{0,073} & \multirow{2}{*}{\multicolumn{2}{|c|}{-}} \\
\hline Iya & $1,85(0,94-3,62)$ & & & \\
\hline \multicolumn{5}{|l|}{ Tinggi badan ibu } \\
\hline$\geq 150 \mathrm{~cm}$ & Ref & \multirow{2}{*}{$0,038^{\#}$} & & \\
\hline$<150 \mathrm{~cm}$ & $2,09(1,04-4,19)$ & & - & \\
\hline Praktik cuci tangan ibu & & & & \\
\hline Higienis & Ref & & & \\
\hline Kurang higienis & $1,38(0,65-2,91)$ & 0,402 & - & \\
\hline Sumber air minum & & & & \\
\hline Bukan PDAM & Ref & & & \\
\hline PDAM & $0,90(0,45-1,83)$ & 0,773 & - & \\
\hline
\end{tabular}


Tabel 3 menunjukkan bahwa variabel perancu yang mengganggu hubungan antara berat badan lahir dan kejadian stunting adalah usia anak, usia ibu saat melahirkan, kepemilikan jamban sehat dan pendapatan keluarga per bulan. Anak yang lahir dengan berat lahir rendah berpeluang 4,7 kali lebih tinggi untuk mengalami stunting dibandingkan anak yang lahir dengan tidak BBLR setelah dikontrol oleh variabel usia anak, usia ibu saat melahirkan, kepemilikan jamban dan pendapatan keluarga per bulan $(95 \% \mathrm{CI}=1,44-15,14$; $p$ value $=0,010$ ). Hal ini menunjukkan bahwa kejadian stunting tidak hanya dipengaruhi dari single cause yang dalam hal ini adalah berat badan lahir, namun dipengaruhi oleh berbagai faktor lainnya (multiple cause).

\section{PEMBAHASAN}

Upaya penurunan proporsi anak balita stunting dan bayi dengan BBLR merupakan 2 dari 4 target upaya perbaikan gizi di dunia (Global Nutrition Targets 2025) yaitu menurunkan proporsi anak balita yang stunting sebesar $40 \%$ dan menurunkan proporsi anak yang lahir dengan berat badan rendah sebesar $30 \%{ }^{1}$ $\mathrm{Hal}$ ini menunjukkan bahwa penurunan proporsi BBLR berkontribusi terhadap penurunan proporsi balita stunting. Berdasarkan hasil penelitian diperoleh prevalensi stunting pada anak usia 6-59 bulan di Kecamatan Seberang Ulu I sebesar 39,4\% dan proporsi BBLR sebesar 8,5\%. Hal ini menunjukkan bahwa stunting di Kecamatan Seberang Ulu I termasuk masalah kesehatan masyarakat dengan prevalensi tinggi (30-39\%) dan proporsi BBLR lebih tinggi daripada proporsi BBLR di Sumatera Selatan $(6,8 \%){ }^{2}$ Sementara itu, prevalensi stunting lebih tinggi pada anak yang lahir dengan BBLR $(68,8 \%)$ dibandingkan tidak BBLR $(36,6 \%)$.

Hasil analisis menunjukkan bahwa terdapat hubungan antara BBLR dengan kejadian stunting pada anak usia 6-59 bulan yaitu 4,7 kali lebih berisiko untuk mengalami stunting pada anak dengan riwayat BBLR dibandingkan anak tanpa riwayat BBLR (95\% CI: ,44 15,14). Hasil penelitian ini sejalan dengan hasil penelitian sebelumnya antara lain di Indonesia ${ }^{7,8}$ dan Zambia $^{21}$. Hasil penelitian Sudirman (2008) menemukan bahwa pada bayi BBLR dalam kondisi dismature akan mengalami gagal tumbuh (growth faltering) setelah bayi berusia 2 bulan dan gagal tumbuh ini akan terus terjadi pada periode berikutnya sehingga bayi BBLR tidak akan mencapai panjang badan yang dicapai oleh anak normal yang berarti bahwa kejar tumbuh (catch up growth) tidak memadai. Kejar tumbuh pada anak dengan BBLR berlangsung hingga usia dua tahun. Kondisi gagal tumbuh dan kejar tumbuh yang tidak memadai merupakan suatu kondisi patologis yang akan menyebabkan stunting pada balita. BBLR menandakan pula janin telah mengalami malnutrisi selama di dalam kandungan dan stunting merupakan manifes kondisi malnutrisi dalam jangka waktu lama (kronik). ${ }^{8}$ Sementara itu, saluran pencernaan pada bayi BBLR belum berfungsi dengan baik yang mengakibatkan bayi mengalami gangguan percernaan seperti proses penyerapan lemak dan pencernaan protein dalam tubuh. Hal ini akan menyebabkan kurangnya cadangan zat gizi dalam tubuh bayi sehingga mengganggu pertumbuhan bayi yang apabila keadaan ini terus berlanjut dengan pemberian ASI eksklusif dan makanan pendamping ASI yang tidak tepat, sering mengalami penyakit infeksi dan lingkungan yang tidak sehat dapat menyebabkan anak mengalami stunting. ${ }^{4}$

Pencegahan bayi lahir dengan BBLR dan stunting harus dimulai dari awal proses kehamilan (prakonsepsi) dengan mempersiapkan remaja putri menjadi calon ibu yang sehat. Namun, hasil Riskesdas menunjukkan bahwa sebanyak 36,3\% remaja putri berusia 15-19 tahun mengalami Kurang Energi Kronis (KEK). Pada Wanita Usia Subur (WUS) 15-49 tahun, sebanyak $17,3 \%$ yang ketika hamil berisiko KEK pada tahun 2018. KEK pada remaja putri dan ibu hamil merupakan salah satu masalah gizi yang disebabkan kekurangan energi dalam jangka waktu yang cukup lama dan juga merupakan hasil kumulatif dari keadaan kurang gizi sejak masa janin, bayi dan kanak-kanak, dan berlanjut hingga dewasa. KEK dapat menganggu pertumbuhan otak janin terutama pada trimester pertama kehamilan. ${ }^{22}$ Kegagalan kenaikan berat badan ibu pada trimester I dan II juga akan meningkatkan proporsi bayi BBLR. Sementara itu, kondisi ibu hamil yang juga pendek $(<150 \mathrm{~cm})$, sebanyak $28,3 \%$ yang akan berdampak pada bayi yang dilahirkan untuk mengalami kurang gizi, dengan BBLR $(<2500$ gram) dan juga panjang badan yang kurang dari $48 \mathrm{~cm}$ sebanyak $5,1 \%$ di Sumatera Selatan. ${ }^{2}$ BBLR dapat dicegah melalui diit ibu yang baik sebelum hamil maupun selama hamil terutama pada trimester II dan III dikarenakan janin mulai tumbuh pesat yang mencapai 10 gram per hari. Oleh karena itu, ibu hamil membutuhkan tambahan 15\% zat gizi (karbohidrat, protein, lemak, vitamin, dan mineral) secara proporsional selama kehamilan yang dipergunakan sebanyak $40 \%$ untuk pertumbuhan janin dan $60 \%$ untuk memenuhi kebutuhan ibu. Namun, berdasarkan tingkat kecukupan kalori dan protein, rata-rata konsumsi kalori penduduk Kota Palembang belum memenuhi standar angka kecukupan gizi, sedangkan konsumsi protein sudah berada di atas angka kecukupan gizi. ${ }^{23}$

Hasil penelitian ini juga menunjukkan bahwa usia anak merupakan salah satu confounder. Hasil penelitian menunjukkan bahwa diantara anak yang berusia 6-23 bulan, proporsi stunting pada anak BBLR $(50,0 \%)$ lebih banyak dibandingkan anak yang tidak BBLR $(30,8 \%)$. Sementara itu, diantara anak yang 
berusia 24-59 bulan, proporsi stunting pada anak yang lahir dengan BBLR dan tidak BBLR adalah 80,0\% dan $39,2 \%$. Hasil penelitian ini sejalan dengan temuan Rahman et al. yang menyatakan bahwa proporsi stunting pada anak BBLR (31,8\%) lebih banyak dibandingkan anak yang normal $(18,1 \%)$ diantara anak yang berusia $<12$ bulan dan diantara anak yang berusia 25-59 bulan adalah $53,9 \%$ dan $42,7 \%{ }^{24}$ Stunting merupakan kondisi gagal tumbuh pada anak balita akibat kekurangan gizi kronis yang dipengaruhi dari kondisi ibu/ calon ibu, masa janin, masa bayi/ balita dan penyakit yang diderita selama masa balita. Masa balita adalah masa yang paling kritis yang akan menentukan kualitas manusia pada usia selanjutnya terutama pada 1000 Hari Pertama Kehidupan (HPK) dikarenakan 80\% pertumbuhan otak terjadi pada masa usia emas tersebut (Golden Age). Oleh karena itu, penanggulangan balita stunting paling efektif dilakukan pada 1000 HPK, sehingga prevalensi stunting pada anak usia 24-59 bulan dapat diturunkan. Hal ini sejalan dengan hasil Riskesdas tahun 2018 yang menunjukkan bahwa prevalensi stunting pada anak usia 0-23 bulan (baduta) sebesar $29,9 \%$ dengan prevalensi tertinggi pada usia $12-$ 23 bulan (37,7\%), sedangkan sebanyak 30,8\% anak usia $0-59$ bulan (balita) mengalami stunting. ${ }^{2}$

Pengolahan lebih lanjut dari hasil penelitian juga menunjukkan bahwa proporsi bayi BBLR lebih banyak dari ibu yang berusia $<20$ atau $>35$ tahun pada saat melahirkan (20,5\%) dibandingkan usia 20-35 tahun $(4,9 \%)$. Pengaturan usia yang ideal untuk melahirkan merupakan intervensi gizi sensitif yang berkontribusi sebesar $70 \%$ dalam penurunan stunting khususnya dalam menyediakan akses kepada layanan kesehatan dan keluarga berencana (KB) yaitu penguatan Komunikasi, Informasi dan Edukasi (KIE) terkait Program Kependudukan, Keluarga Berencana dan Pembangunan Keluarga (KKBPK). Usia ideal bagi seorang wanita untuk hamil dan melahirkan adalah antara usia 20-35 tahun dikarenakan risiko wanita menghadapi komplikasi medis tergolong yang paling rendah. Wanita yang hamil pada usia muda, (<20 tahun) dari segi biologis perkembangan alat-alat reproduksi belum sepenuhnya optimal sehingga sering mendapat gangguan kesehatan Sedangkan, wanita yang hamil pada usia terlampau tua ( $>35$ tahun), fungsi alat reproduksinya telah mengalami kemunduran dan munculnya kelainan-kelainan yang bersifat degeneratif seperti penyakit hipertensi, diabetes mellitus dan lain sebagainya. Hasil penelitian ini sejalan dengan penelitian sebelumnya. ${ }^{725-27}$

Hasil temuan dalam penelitian ini adalah diantara keluarga yang tidak memiliki jamban sehat, proporsi bayi BBLR yang mengalami stunting $(100 \%)$ lebih tinggi dibandingkan bayi tidak BBLR $(52,6 \%)$. Hasil penelitian ini sejalan dengan penelitian sebelumnya. ${ }^{10}$ Akses pada sanitasi juga merupakan salah satu intervensi gizi sensitif yang berkontribusi sebesar 70\% dalam penurunan stunting. Berdasarkan Statistik Kesejahteraan Rakyat Kota Palembang tahun 2018, pada keluarga dengan kelompok pengeluaran $40 \%$ terbawah memiliki persentase tertinggi $(15,6 \%)$ rumah tangga yang tidak ada/ tidak menggunakan fasilitas buang air besar (BAB) diantara $40 \%$ tengah $(7,7 \%)$ dan $20 \%$ teratas $(6,1 \%) .{ }^{23}$ Hal ini sesuai dengan hasil penelitian yang menunjukkan bahwa keluarga dengan pendapatan per bulan di bawah UMK $(13,9 \%)$ dan minimum UMK $(6,2 \%)$ tidak memiliki jamban sehat.

Pendapatan keluarga per bulan juga merupakan faktor perancu antara hubungan berat badan lahir dengan kejadian stunting. keluarga dengan pendapatan di bawah UMK, bayi BBLR $(88,9 \%)$ lebih banyak mengalami stunting dibandingkan bayi yang tidak BBLR $(42,4 \%) \quad(\mathrm{OR}=1,94 ; 95 \% \quad \mathrm{CI}=1,03-3,65, \quad p=$ 0,040). Hasil penelitian ini sejalan dengan Rahman et al. yang menyatakan bahwa bayi BBLR yang mengalami stunting lebih banyak dibandingkan bayi dengan berat lahir normal pada berbagai status sosial ekonomi antara lain sangat miskin $(63,2 \%)$, miskin $(54,9 \%)$, menengah $(49,6 \%)$, kaya $(47,6 \%)$ dan sangat kaya $(32,5) .^{24}$ Keluarga dengan pendapatan rendah bermasalah dalam akses terhadap makanan dikarenakan daya beli yang rendah pula. Berdasarkan Statistik Kesejahteraan Rakyat Kota Palembang tahun 2018, rata-rata pengeluaran per kapita sebulan pada kelompok $40 \%$ terbawah masih didominasi oleh umbi-umbian dan rokok/ tembakau dan bukan pada pengeluaran akan makanan tinggi protein dan vitamin/ mineral seperti ikan/udang/cumi/ kerang, daging, telur dan susu, sayuran, buah-buahan, kacang-kacangan dan padipadian. ${ }^{23}$ Hal ini menunjukkan bahwa perilaku konsumsi makanan bergizi masih rendah. Hal ini bertolak belakang dengan tingginya komoditas ikan di Kota Palembang.

\section{SIMPULAN}

BBLR berhubungan dengan kejadian stunting pada balita usia 6-59 bulan di Kecamatan Seberang Ulu I Palembang dengan faktor perancu antara lain usia anak, usia ibu saat melahirkan, kepemilikan jamban dan pendapatan keluarga per bulan sedangkan, panjang badan lahir, jenis kelamin, perilaku cuci tangan ibu dan sumber air minum tidak berhubungan dengan kejadian stunting pada hasil penelitian ini.

Peningkatan perilaku dalam mengkonsumsi makanan bergizi secara seimbang selama masa sebelum kehamilan, pada saat kehamilan dan setelah melahirkan dapat mencegah anak mengalami BBLR dan stunting. Selain itu, perlu diberikan edukasi kesehatan kepada ibu dan balita beserta suami dan keluarga. 


\section{UCAPAN TERIMA KASIH}

Peneliti mengucapkan terima kasih kepada Lembaga Penelitian dan Pengabdian kepada Masyarakat (LP2M) Universitas Sriwijaya, serta Fakultas Kesehatan Masyarakat dan enumerator yang telah membantu dalam penyelesaian penelitian ini.

\section{DAFTAR PUSTAKA}

1. Kementerian Kesehatan RI. Situasi Balita Pendek (Stunting) Di Indonesia. Jakarta: Pusat Data dan Informasi Kementerian Kesehatan RI; 2018.

2. Kementerian Kesehatan RI. Laporan Nasional RISKESDAS 2018. Jakarta: Badan Penelitian dan Pengembangan Kesehatan Kementerian Kesehatan RI; 2019.

3. Supriyanto Y, Astria PB, Astiti D. Berat Badan Lahir Rendah Berhubungan Dengan Kejadian Stunting Pada Anak Usia 6-23 Bulan. Jurnal Gizi dan Dietetik Indonesia. 2017;5(1):23-30.

4. Nasution D, Siti ND, Huriyati E. Berat Badan Lahir Rendah (BBLR) Dengan Kejadian Stunting Pada Anak Usia 6-24 Bulan. Jurnal Gizi Klinik Indonesia. 2014;11(1):31-7.

5. Lestari W, Margawati A, Rahfilludin MZ. Faktor Risiko Stunting Pada Anak Usia 6-24 Bulan Di Kecamatan Penanggalan Kota Subulussalam Provinsi Aceh. Jurnal Gizi Indonesia. 2014;3(1):37-45.

6. Mustikaningrum AC, Subagio HW, Margawati A. Determinan Kejadian Stunting Pada Bayi Usia 6 Bulan Di Kota Semarang. Jurnal Gizi Indonesia. 2016;4(2):82-8.

7. Sajalia H, Lanti RDY, Murti B. Life Course Epidemiology on the Determinants of Stunting in Children Under Five in East Lombok, West Nusa Tenggara. Journal of Maternal and Child Health. 2018;3(4):242-51.

8. Wellina WF, Kartasurya MI, Rahfilludin MZ. Faktor Risiko Stunting Pada Anak Usia 12-24 Bulan. Jurnal Gizi Indonesia. 2016;5(1):55-61.

9. Widyaningsih NN, Kusnandar, Anantanyu S. Keragaman Pangan, Pola Asuh Makan Dan Kejadian Stunting Pada Balita Usia 24-59 Bulan. Jurnal Gizi Indonesia. 2018;7(1):22-9.

10. Asfaw M, Wondafrash M, Taha M, Dube L. Prevalence of Undernutrition and Associated Factors among Children Aged between Six to Fifty Nine Month $\mathrm{s}$ in Bule Hora District, South Ethiopia. BMC Public Health. 2015;15(41):1-9.

11. Mgongo M, Chotta NAS, Hashim TH, Uriyo JG, Damian DJ, Stray-Pedersen B, et al. Underweight, Stunting and Wasting among Children in Kilimanjaro Region, Tanzania; a Population-Based Cross-Sectional Study. International Journal of
Environmental Research and Public Health. 2017;14(509):1-12.

12. Mawa R, Lawoko S. Malnutrition Among Children Under Five Years in Uganda. American Journal of Health Research. 2018;6(2):56-66.

13. Ntenda P, Chuang Y-C. Analysis of IndividualLevel and Community-Level Effects on Childhood Undernutrition in Malawi. Pediatrics \& Neonatology. 2018;59(4):380-9.

14. Amare D, Abejie A, Tsegaye B, Assefa B, Ayenie B. Prevalence of Undernutrition and Its Associated Factors among Children below Five Years of Age in Bure Town, West Gojjam Zone, Amhara National Regional State, Northwest Ethiopia. Advances in Public Health. 2016;2016:1-8.

15. Girma A, Woldie H, Mekonnen FA, Gonete KA, Sisay M. Undernutrition and Associated Factors among Urban Children Aged 24-59 Months in Northwest Ethiopia: A Community Based Cross Sectional Study. BMC Pediatrics. 2019;19(214):111.

16. Sethy G, Jena D, Jena P, Pradhan S, Biswas T. Prevalence of Malnutrition among under Five Children of Urban Slums of Berhampur, Odisha, India: A Community Based Cross-Sectional Study. International Journal of Contemporary Pediatrics. 2017;4(6):2180-6.

17. Batiro B, Demissie $T$, Halala $Y$, Anjulo AA. Determinants of Stunting among Children Aged 659 Months at Kindo Didaye Woreda, Wolaita Zone, Southern Ethiopia: Unmatched Case Control Study. PloS ONE. 2017;12(12):1-15.

18. Khan G, Turab A, Imran Khan M, Rizvi A, Shaheen F, Ullah A, et al. Prevalence and Associated Factors of Malnutrition among Children Under-Five Years in Sindh, Pakistan: A Cross-Sectional Study. BMC Nutrition. 2016;2(69):1-7.

19. Nkurunziza S, Meessen B, Van geertruyden J-P, Korachais C. Determinants of Stunting and Severe Stunting among Burundian Children Aged 6-23 Months: Evidence from a National Cross-Sectional Household Survey, 2014. BMC Pediatrics. 2017;17(176):1-14.

20. Dinas Kesehatan Kota Palembang. Profil Kesehatan Tahun 2017. Palembang: Dinas Kesehatan Kota Palembang; 2018.

21. Bwalya B, Lemba M, Mapoma C, Mutombo N. Factors Associated with Stunting among Children Aged 6-23 Months in Zambian: Evidence from the 2007 Zambia Demographic and Health Survey. International Journal of Advanced Nutrition and Health Sciences. 2015;3(1):116-31.

22. Kementerian Kesehatan RI. Pedoman Pelaksaaan Stimulasi, Deteksi Dan Intervensi Dini Tumbuh Kembang Anak. Jakarta: Kementerian Kesehatan 
RI; 2016.

23. BPS Kota Palembang. Statistik Kesejahteraan Rakyat Kota Palembang. Palembang: Badan Pusat Statistik Kota Palembang; 2018.

24. Rahman MS, Howlader T, Masud MS, Rahman ML. Association of Low-Birth Weight with Malnutrition in Children under Five Years in Bangladesh: Do Mother's Education, SocioEconomic Status, and Birth Interval Matter? PloS ONE. 2016;11(6):1-16.

25. Restrepo-Méndez MC, Lawlor DA, Horta BL, Matijasevich A, Santos IS, Menezes AMB, et al.
The Association of Maternal Age with Birthweight and Gestational Age: A Cross-Cohort Comparison. Paediatr Perin Epidemiol. 2015;29:31-40.

26. Siramaneerat I, Agushybana F, Meebunmak Y. Maternal Risk Factors Associated with Low Birth Weight in Indonesia. The Open Public Health Journal. 2018;11:376-83.

27. Siyoum M, Melese T. Factors Associated with Low Birth Weight among Babies Born at Hawassa University Comprehensive Specialized Hospital, Hawassa, Ethiopia. Italian Journal of Pediatrics. 2019;45(48):1-7. 